\title{
Population Problems in the Pacific*
}

CINCE the publication of Rivers's "Essays on the $\checkmark$ Depopulation of Melanesia" in 1922, much attention has been given to the population problem in the Pacific and the causes of the decrease in numbers of the natives. A discussion at the Sydney meeting of the Australian and New Zealand Association for the Advancement of Science afforded a welcome opportunity for taking stock of the advance that has been made in the interval towards a real understanding of the factors involved. So far as it is possible to draw any general conclusions from the observations which were reported in the discussion and the inferences drawn from them, it would appear that while the psychological factor, on which Rivers laid so much stress, is still regarded as of importance, there is a tendency to attach greater significance to food and the need for medical attention. On the other hand, it is evident that there has been some change--perhaps even in a considerable degree-in conditions since the time when Rivers's observations were made. Some of the populations appear to be approaching, or even to have attained, a state of equilibrium in their contact with Europeans. Where this is occurring, credit must undoubtedly be given to wise methods of administration.

The discussion was opened by Sir Hubert Murray, president of the Association, who was in the chair. In a communication on "Depopulation in Papua" he said that while there is no evidence of depopulation in general, there is a decline in the Eastern Division and the South-Eastern Division. The main causes he believes to be three-insufficient food-supply, disease and the passing of the old modes of life. His conclusion is that some tribes may succumb altogether, but the more resistant stocks will remain and their natural increase will be more than enough to make up the loss. He advocated the introduction of new foods rich in vitamins, and the extension of the activities of medical officers.

Mr. E. W. P. Chinnery, of the New Guinea administrative service, pointed out the necessity for a census and Mr. F. E. Williams, Government anthropologist of Papua, while arguing that the administrator must apply the conclusions reached by science, suggested certain lines of action which should be taken forthwith by the administration while scientific workers are continuing their investigations. The factors in the depopulation problem, he holds, fall into two classes, pre-European and postEuropean. The pre-European factors, native warfare, sorcery and certain sexual practices, act as checks and must be removed. Among post-European factors are introduced disease and the loss of interest in life, these being of major importance, while of minor importance are increasing masculinity and the decline of polygamy. He stressed the importance of the limitations of the food supply.

Prof. Raymond Firth in "Indices of a Stable Population" dealt with the population of Tikopia, where the factors of fertility are outstripping those of morbidity and the population is increasing. This is due chiefly to the fact that former checks are inoperative. Hence pressure is being put on the food supply, much to the consternation of the old men. This last aspect of the problem of population was

* From the report of a discussion on "Population Problems", Australian and New Zealand Association for the Advancement of Science, Sydney Meeting, August, 1932. Oceania, 3, No. 1, 91-100. also considered in a communication of a more general character from Prof. S. H. Roberts, who laid stress on the economic factor and advocated the intervention of the administration to secure economic regeneration. Dr. Ian Hogbin, dealing specifically with the causes of depopulation, examined the contention that the islands were becoming depopulated before the arrival of the European on the scene, and the actual evidence for an increase in the death-rate and its causes. Prof. J. Macdonald Holmes, taking into account the number of extraterritorial peoples, especially Indians and Chinese, now resident in the Pacific, also dwelt on the economic factor, and inquired whether trade relegated the native to an inferior position and broke down tribal or family organisation.

A valuable communication on "The Medical Sciences in Relation to Depopulation" by Dr. R. W. Cilento followed. He divided the effects of European intrusion on native races into three stages. In the first, attack by arms, by new diseases and by dislocation of tribal life caused an enormous decline. This stage has long passed in the Pacific. The second stage is one of partial adjustment, when the European seeks to impose his scale of values on the native. The native loses the safeguards of savagery and, as he fails to get a substitute, a state of disequilibrium follows. This is to be seen in many parts of Melanesia. Finally, either the factors for decline predominate and the native race disappears. or adjustment becomes gradually complete and the population begins steadily to increase. Of the causes of depopulation, by far the most important are disease and food deficiency. The psychological factor, Dr. Cilento believes, is not the cause of depopulation, but merely an effect. Mental lassitude and bodily weariness follow chronic disease and prevent anything but the most essential tillage of the soil, thus providing and accentuating a vicious circle by further impoverishing the diet. The attitude of hopelessness is not a primary condition resulting from the disruption of native custom. The best method of attacking the depopulation problem is by going to the root of the trouble, devoting more attention to medical services and improving native diet by providing foods rich in protein and vitamins $A, C$ and $E$. The lack of fertility is correlated with the lack of vitamin $\mathrm{E}$, in which native foods are especially poor.

Dr. W. M. Strong also dealt with this aspect of the problem in his communication on the "Nutritional Aspects of Depopulation and Disease". He stressed the importance of vitamins in the diet, especially of indentured labourers, and quoted cases in which beriberi and scurvy have been cured by changes of diet, while he thinks that even tuberculosis might be averted by the provision of good nourishing food. Influenza epidemics have always caused more deaths in Papua when they have followed a drought. He urged the cultivation of a greater variety of native crops.

Dr. T. Wi-Repa pointed out that since the last century, when it was feared the Maori would die out, the population has increased.

The work of the missions in relation to the question of depopulation both in the past and at the present time was discussed by the Rev. J. W. Burton and the Rev. J. S. Needham, who pointed out that the missions not only check harmful customs such as 
infanticide, but also provide new interests, such as organised games, which take the place of warfare.

The discussion closed with an important paper by Dr. A. P. Elkin on "The Cultural and Racial Clash in Australia", which in its broader implications has a bearing on native problems in a wider field than that with which it deals immediately. He pointed out that the coming of civilisation brought about a sudden change in the environment of the aborigines of Australia. Before the advent of the white man, the aborigines had reached an almost static condition of equilibrium, which was maintained by an intricate, but logical, system of social, legal, religious and technical customs, ensuring the cohesion, solidarity and persistence of the aboriginal race in its environment. The change worked by the coming of the white man has been almost as hard, objective, and inhuman as a geographical change. Tribal and horde grounds, which were associated with the past through sacred sites and beliefs, are used by the white man for his own purposes. Being unable to perform the initiatory, historical and totemic rites in the way and at the sites sanctified by tradition, the aboriginal feels that there can be no future for him and prepares to die. Being unable to adapt himself to this new environment, he has rapidly decreased in numbers. The Australian race is another example of a type so specialised and adjusted to one environment that it cannot adapt itself to another.

\section{Thomas Norton and the "Ordinall of Alchimy"}

$\mathrm{A}^{\mathrm{s}}$ $S$ one of the earliest alchemical books in English, the "Ordinall of Alchimy" is of much interest; Dr. M. Nierenstein and Mr. P. F. Chapman are therefore to be thanked for their exhaustive inquiry (Isis, $18,290-321$; 1932) into its authorship. Ashmole, in his "Theatrum Chemicum Britannicum", is the chief authority for ascribing the "Ordinall" to Thomas Norton of Bristol, who was supposed to have flourished in the fifteenth century. Ashmole's evidence for the authorship of this anonymous poem was that "from the first word of this Proeme, and the Initiall letters of the six following Chapters [namely, "Tomais Norton of Briseto'] . . . we may collect the Authors Name and place of Residence". As for the date of the book, there is the statement at the end of the seventh chapter: "In this yeare of Christ One thousand foure Hundred seaventy and seaven, This Warke was begun, Honour to God in Heaven".

Dr. Nierenstein and $\mathrm{Mr}$. Chapman, from a consideration of the language of the poem, and of the authorities quoted in it, regard the date 1477 as, in all probability, correct; and Dr. Peter Haworth, whom they consulted, says that the "Ordinall" certainly belongs to the second half of the fifteenth century. The problem of authorship is, however, more confused. Dr. Nierenstein and Mr. Chapman say that Norton's name, in connexion with the "Ordinall", became known only in 1617-18, when Michael Maier mentions him as a master of alchemy who wrote in English verse, and published a Latin version of the "Ordinall" in his "Tripus Aureus". They do not, however, notice that (according to Mrs. Singer's "Catalogue of Latin and Vernacular Alchemical Manuscripts", 2, 556-7; 1930) two fifteenth century manuscripts of the poem exist, in which the author is described as "T. N." This would appear to afford weighty support to Ashmole's 'cipher' theory; though it does not necessarily follow that "T. N." belonged to the well-known
Bristol family of which he is usually described as a member.

Dr. Nierenstein and Mr. Chapman have very carefully and thoroughly sought out the records of the Bristol Nortons, and have constructed a genealogical table of the family, covering the relevant period, so far as is necessary to establish the interrelationship of those members named Thomas. There appeared to be four Thomas Nortons, and four only, for whom any case could be made out as possible authors of the "Ordinall". Thomas Norton I was alive in 1388, and may therefore be safely rejected. Thomas Norton II is equally ruled out, as his will was proved in 1449. As to Thomas Norton IV, he was certainly dead in 1479, and it is extremely unlikely that he was alive in 1477. There remains Thomas Norton III, who, as great-grandfather of the alchemist Samuel Norton (1548-1604 ?), would seem to have the best claim, since Samuel refers to his ancestor as an alchemist. However, Thomas III also is unacceptable to Dr. Nierenstein and Mr. Chapman, who state that he was a thoroughly disreputable character, according to the Bristol records, "avoiding divine service" and spending "sermon time in the afternoon at tennis and frivolous sports". His will was dated November 26,1513 , and the authors think that he must have died soon after.

The conclusion at which Dr. Nierenstein and $\mathrm{Mr}$. Chapman arrive is that Maier and Ashmole were not justified in definitely ascribing the anonymously written "Ordinall" either to "Thomas Norton" or to "Thomas Norton of Bristol". While no fault can be found with this cautious statement, it yet seems probable that Maier and Ashmole were correct; and in view of the well-known character of many alchemists, it is perhaps surprising that Dr. Nierenstein and Mr. Chapman did not consider that Thomas Norton III - who, on chronological and other grounds, is obviously eligible--has a strong claim on the very grounds of his disreputability. F. J. HoLmyarD.

\section{Prehistoric Society of East Anglia}

A the annual business meeting of the Prehistoric A Society of East Anglia held on February 18, Dr. Cyril Fox, director of the National Museum of Wales, was elected president for the year 1933, Prof. V. Gordon Childe, vice-president, and Mr. G. Maynard, of the Ipswich Museum, general secretary.

After the business meeting, specimens were exhibited and papers read. Mr. R. N. Chandler sent an account of his researches during the past six years in the basal gravel of the Swanscombe Terrace of the Thames Valley, where he had obtained more than 200 implements belonging to Stages 1 and 2 of the Clactonian culture. Fully 50 per cent of the artefacts are cores of which the chopping tool characteristic of 